\title{
Variability in nutrient composition of cereal grains from different origins
}

Jinyoung Lee, Doo Seok Nam and Changsu Kong*

\begin{abstract}
Nutrient composition of individual feed ingredient in mixed feed is important for accurate formulation of animal feeds. However, each feed ingredient can be different depending on its origin. Therefore, this study was conducted to investigate the variability in nutrient compositions of corn, wheat, and barley grains from different origins. Cereal grains used in this study were from 5 countries for 432 corn samples, 5 countries for 65 wheat samples, and 3 countries for 60 barley samples. They were imported to Korea between 2006 and 2015. These grain samples were subjected to analysis for moisture, crude protein (CP), ether extract (EE), crude fiber (CF), ash, calcium (Ca), phosphorus (P), and gross energy (GE). The concentrations of moisture, $C P, E E, C F$, ash, $C a, P$, and $G E$ of corn differed $(P<0.05)$ among countries. GE in corn samples ranged from $3836 \mathrm{kcal} / \mathrm{kg}$ (Ukraine) to $3995 \mathrm{kcal} / \mathrm{kg}$ (Brazil). There were also differences $(P<0.05)$ in moisture, $C P$, ash, and $P$ of wheat and in moisture, $C F, C a$, $P$, and $G E$ in barley from different countries. GE values in wheat ranged from $3957 \mathrm{kcal} / \mathrm{kg}$ (Brazil) to $4058 \mathrm{kcal} / \mathrm{kg}$ (United States) and GE values in barley samples ranged from $3894 \mathrm{kcal} / \mathrm{kg}$ (India) to $4059 \mathrm{kcal} / \mathrm{kg}$ (Australia). The most different nutrient depending on origins was $\mathrm{Ca}$. The coefficient of variation was $65.7 \%$ for corn, $57.4 \%$ for wheat, and $28.8 \%$ for barley. In conclusion, nutrients and energy contents in corn, wheat, and barley from various origins investigated in the present study were different. Therefore, it is important to consider these variations when formulating animal feeds.
\end{abstract}

Keywords: Barley, Corn, Location, Variation, Wheat

\section{Background}

The purpose of formulating animal diet is to improve the productivity by providing feed that meets nutrient requirements accurately. Therefore, it is important to formulate mixed diet through correct evaluating nutrient components in feed ingredients. According to a report by Korean authorities, annual feed production is about 19 million tons (Ministry of Agriculture, Food and Rural Affairs, MAFRA 2015). Most ingredients for animal feed is imported from overseas, with cereal grains usually accounting for approximately $60 \%$ in animal feed as an energy source. Among cereal grains imported from other countries, corn is imported at the largest amount. Its nutrient compositions can vary due to many factors, including genetic and environmental factors (Watson and Ramstad 1987; Skogerson et al. 2010). In addition,

*Correspondence: changsukong@gmail.com

Department of Animal Science and Technology, Konkuk University,

Seoul 05029, Republic of Korea wheat is widely-used in European countries. Nutrient contents of wheat can also vary due to several factors, including cultivars (Murphy et al. 2008) and environmental factors (Acharya and Sharma 1994). Barley is ranked the third among cereal grains used for feed in the United States. It is often used in human food and animal feed (Jadhav et al. 1998). Nutrient compositions of barley can also vary depending on genetic and environmental factors (MacGregor and Bhatty 1993; Jadhav et al. 1998). Because of these reasons, it is important to investigate nutrient values of cereal grains according to their origins so that feed formulation can be accurate. However, only a few studies have compared nutrient compositions in corn. No study has reported the variability in nutrient compositions of wheat and barley from different countries. Therefore, the objective of this study was to determine the variability in nutrient compositions of corn, wheat, and barley grains from different countries. 


\section{Experimental procedures Ingredients data}

The present study was conducted by using data from laboratories of major feed companies in Korea to understand the variations in nutrients of cereal grains imported to Korea from different countries. Corn and wheat nutrients data were from 2006 to 2015. Barley nutrients data were from 2010 to 2015 . Corn grain was the main cereal grain imported to Korea. A total of 432 corn samples imported from 5 countries (Argentina, Brazil, China, Ukraine, and United States), 65 wheat samples from 5 countries (Australia, Brazil, India, Ukraine, and United States), and 60 barley samples from 3 countries (Australia, India, and Ukraine) were analyzed in this study.

\section{Chemical analysis}

Cereal grain samples were analyzed for moisture, crude protein $(\mathrm{CP})$, ether extract $(\mathrm{EE})$, crude fiber $(\mathrm{CF})$, ash, calcium (Ca), phosphorus (P), and gross energy (GE). All the chemical analyses were performed at the same laboratory with using same methodology for each nutrient and energy. Dry matter analysis was performed by drying in an oven at $135^{\circ} \mathrm{C}$ for $2 \mathrm{~h}$ (method 930.15; AOAC, 2005). Analysis of CP was determined by using Dumas combustion method (Leco, St. Joseph, MI, USA). EE was analyzed after extracting crude fat with ether (method 920.39; AOAC, 2005). CF was analyzed using Ankom filter bag technique (Ankom technology, Macedon, NY, USA). Ash was determined with AOAC method 942.05. $\mathrm{Ca}$ and $\mathrm{P}$ were determined using inductively coupled plasma spectroscopy (method 985.91; AOAC, 2005). GE was determined with bomb calorimeter (IKA Calorimeter C 2000 basic; IKA-Werke GmbH, Staufen, Germany).

\section{Statistical analysis}

Data were analyzed using GLM procedures of SAS (SAS Inst. Inc., Cary, NC, USA). The model consisted of country as an independent variable and nutrients as dependent variables as well as error term. The origin of country for all ingredients investigated had no interaction with year (data not shown). Therefore, pooled data averaged across year were used in the present study. In addition, the concentrations of nutrient in each country were not correlated to years (data not shown). An $\alpha$-level of statistical significance was set at 0.05 . Outliers that deviated 1.5 times of the interquartile ranges below the first quartile or above the third quartile were removed.

\section{Results and discussion}

Although it is easier to compare nutrient values using "dry matter" basis than using "as-is" basis, every nutrient concentration was expressed in "as-is" basis in this study, because feed formulation is conducted at "as-is" basis in practice. Nutrient composition of feed ingredients in the swine NRC (2012) is widely used to compare nutritive values of ingredients. In addition, the values of NRC (2012) contain results of numerous studies. Therefore, they were used as references to discuss results of this study.

\section{Variation among countries}

All nutrient concentrations evaluated for corn were different $(P<0.05)$ among countries (Table 1$)$. The concentration of $\mathrm{CP}$ in corn ranged from $7.12 \%$ from Brazil to $7.60 \%$ from China. This range was slightly smaller than the range of 7.31-9.06 \% reported by Cromwell et al. (1999) who investigated CP concentration of corn from various parts of the United States. This range was also smaller than the CP value of NRC (2012) at $8.24 \%$ and that of CVB (2009) at $8.20 \%$. The EE content in corn varied from $3.30 \%$ (United States) to $3.87 \%$ (Brazil). The concentrations of $\mathrm{Ca}$ in corn from all the countries were fairly consistent to reported values at $0.02 \%$ in NRC (2012) and CVB (2009) except a greater Ca content $(0.04 \%)$ in the corn from Ukraine. Phosphorus concentrations in corn ranged from $0.20 \%$ (Brazil) to $0.23 \%$ (Ukraine and United States), which were slightly lower compared to reported values (average of $0.26 \%$ ) by Cromwell et al. (1999). GE values in corn ranged from $3836 \mathrm{kcal} / \mathrm{kg}$ (Ukraine) to $3995 \mathrm{kcal} / \mathrm{kg}$ (Brazil). The GE contents in corn from this study were fairly consistent with values listed in NRC (2012). Brazil had relatively higher concentration of GE compared to other countries. This might be due to the relatively higher concentration of EE (3.87 \%) in corn from Brazil. Ewan (1989) has suggested that the components in the prediction equation for GE are CP, EE, and ash and that GE is positively correlated to the concentration of EE. Many factors can affect the variation in nutrient components of corn, including cultivar (Feil et al. 2005; Ufaz and Galili 2008), fertilization (Kaiser et al. 2005), soil condition (Harder et al. 1982), and occurrence of toxins (Abbas et al. 2006). There have been efforts to improve nutrient composition of corn. Genetic approaches have been used to improve cultivars such as 'quality protein maize' with improved the concentration of lysine and tryptophan in seeds (Ufaz and Galili 2008). Therefore, CP content may vary depending on varieties. In addition, Feil et al. (2005) have found that there are significant differences in concentrations of $\mathrm{CP}, \mathrm{P}$, and $\mathrm{Ca}$ in grains of different genotypes. Harder et al. (1982) have shown that corn yield reduced up to $33 \%$ depending on harshness and exposure of moisture stress that can affect nitrogen and consequently increase CP concentration in the corn. Rodrigues and Naehrer (2012) have reported that aflatoxin can be found in corn, soybean meal, wheat, and distillers dried grains 
Table 1 Nutrient compositions of corn from different countries (as-is basis, \%)

\begin{tabular}{|c|c|c|c|c|c|c|c|c|}
\hline & Moisture & $\mathrm{CP}$ & $\mathrm{EE}$ & $\mathrm{CF}$ & Ash & $\mathrm{Ca}$ & $P$ & GE \\
\hline \multicolumn{9}{|l|}{ NRC (2012) } \\
\hline$n$ & 133 & 163 & 115 & 78 & 76 & 61 & 76 & 48 \\
\hline Mean & 11.69 & 8.24 & 3.48 & 1.98 & 1.30 & 0.02 & 0.26 & 3933 \\
\hline$C V$ & 20.62 & 11.29 & 22.41 & 30.81 & 24.62 & 50.0 & 19.23 & 2.19 \\
\hline \multicolumn{9}{|l|}{ CVB (2009) } \\
\hline Mean & 12.80 & 8.20 & 3.80 & 2.20 & 1.20 & 0.02 & 0.27 & $\mathrm{~N} / \mathrm{A}$ \\
\hline \multicolumn{9}{|l|}{ Argentina } \\
\hline$n$ & 30 & 30 & 30 & 30 & 30 & 28 & 30 & 17 \\
\hline Mean & 13.99 & 7.25 & 3.74 & 2.19 & 1.13 & 0.02 & 0.22 & 3869 \\
\hline$C V$ & 3.62 & 4.75 & 13.68 & 12.29 & 8.26 & 54.15 & 18.44 & 2.71 \\
\hline \multicolumn{9}{|l|}{ Brazil } \\
\hline$n$ & 57 & 57 & 56 & 56 & 54 & 51 & 54 & 34 \\
\hline Mean & 13.33 & 7.12 & 3.87 & 2.24 & 1.04 & 0.02 & 0.20 & 3995 \\
\hline CV & 5.13 & 2.90 & 12.33 & 12.27 & 10.77 & 44.97 & 12.49 & 3.47 \\
\hline \multicolumn{9}{|l|}{ China } \\
\hline$n$ & 56 & 56 & 55 & 56 & 56 & 48 & 56 & 56 \\
\hline Mean & 14.39 & 7.60 & 3.62 & 2.27 & 1.14 & 0.02 & 0.21 & 3917 \\
\hline$C V$ & 4.17 & 2.86 & 8.44 & 16.92 & 10.29 & 73.55 & 14.37 & 1.12 \\
\hline \multicolumn{9}{|l|}{ Ukraine } \\
\hline$n$ & 26 & 26 & 26 & 26 & 24 & 18 & 22 & 15 \\
\hline Mean & 13.41 & 7.41 & 3.57 & 2.24 & 1.12 & 0.04 & 0.23 & 3836 \\
\hline$C V$ & 4.97 & 4.98 & 12.20 & 13.45 & 8.06 & 67.92 & 8.42 & 4.14 \\
\hline \multicolumn{9}{|c|}{ United States } \\
\hline$n$ & 263 & 263 & 262 & 262 & 262 & 237 & 260 & 180 \\
\hline Mean & 14.52 & 7.18 & 3.30 & 2.01 & 1.16 & 0.02 & 0.23 & 3902 \\
\hline$C V$ & 3.93 & 5.21 & 12.67 & 12.93 & 8.23 & 71.56 & 12.38 & 2.48 \\
\hline Maximum & 14.52 & 7.60 & 3.87 & 2.27 & 1.16 & 0.04 & 0.23 & 3995 \\
\hline Minimum & 13.33 & 7.12 & 3.30 & 2.01 & 1.04 & 0.02 & 0.20 & 3836 \\
\hline Average & 13.93 & 7.31 & 3.62 & 2.19 & 1.12 & 0.02 & 0.22 & 3904 \\
\hline \multicolumn{9}{|c|}{ Among countries } \\
\hline SEM & 0.13 & 0.08 & 0.10 & 0.06 & 0.02 & 0.003 & 0.01 & 30.2 \\
\hline$P$ value & $<0.001$ & $<0.001$ & $<0.001$ & $<0.001$ & $<0.001$ & $<0.001$ & $<0.001$ & $<0.001$ \\
\hline $\mathrm{CV}$ & 5.32 & 5.17 & 13.73 & 14.39 & 9.50 & 65.68 & 14.57 & 2.82 \\
\hline
\end{tabular}

$C P$ crude protein, $E E$ ether extract, $C F$ crude fiber, $C a$ calcium, $P$ phosphorus, GE gross energy, $C V$ coefficient of variation, SEM standard error of the mean

with solubles from North and South America, Europe, and Asia from January 2009 to December 2011. It has been reported that aflatoxin in corn have been found under several stressful conditions such as drought, high temperatures, and the lack of nutrients in soil (Abbas et al. 2006). These conditions may decrease nutrient components in corn.

The concentrations of moisture, $\mathrm{CP}$, ash, and $\mathrm{P}$ were different $(P<0.05$; Table 2$)$ in wheat samples from different countries. CP concentrations ranged from $10.55 \%$ in wheat from Ukraine to 13.17 \% in wheat from Brazil. Phosphorus concentration in wheat ranged from $0.26 \%$ from Australia to $0.34 \%$ from Brazil. Both $\mathrm{CP}$ and $\mathrm{P}$ values in the current study were closer to the values in CVB (2009) rather than to those of NRC (2012). The lowest GE was $3957 \mathrm{kcal} / \mathrm{kg}$ from Brazil and the highest GE was $4058 \mathrm{kcal} / \mathrm{kg}$ from United States. All GE values in this study were higher than that $(3788 \mathrm{kcal} / \mathrm{kg})$ listed in NRC (2012). Zijlstra et al. (1999) have investigated the mean GE of 16 wheat samples collected from Saskatchewan province of Canada. They reported that the GE was $4608 \mathrm{kcal} / \mathrm{kg} \mathrm{DM}$, which was fairly similar to the GE value of $4512 \mathrm{kcal} / \mathrm{kg}$ DM found in this study. In addition, the mean concentrations of $\mathrm{CP}, \mathrm{EE}, \mathrm{CF}, \mathrm{Ca}$, and $\mathrm{P}$ were consistent between the present study and the study of Zijlstra et al. (1999). Nutrient contents of wheat can vary 
Table 2 Nutrient compositions of wheat from different countries (as-is basis, \%)

\begin{tabular}{|c|c|c|c|c|c|c|c|c|}
\hline & Moisture & $\mathrm{CP}$ & $\mathrm{EE}$ & $\mathrm{CF}$ & Ash & $\mathrm{Ca}$ & $P$ & $\mathrm{GE}$ \\
\hline \multicolumn{9}{|l|}{$\operatorname{NRC}(2012)^{a}$} \\
\hline$n$ & 46 & 64 & 36 & 6 & 25 & 25 & 37 & 25 \\
\hline Mean & 11.33 & 14.46 & 1.82 & 2.57 & 1.98 & 0.06 & 0.39 & 3788 \\
\hline$C V$ & 28.42 & 17.36 & 20.33 & 31.13 & 18.69 & 83.33 & 25.64 & 3.83 \\
\hline \multicolumn{9}{|l|}{ CVB (2009) } \\
\hline Mean & 13.20 & 11.10 & 1.30 & 2.40 & 1.50 & 0.04 & 0.31 & N/A \\
\hline \multicolumn{9}{|l|}{ Australia } \\
\hline$n$ & 12 & 11 & 12 & 12 & 12 & 10 & 12 & 7 \\
\hline Mean & 10.23 & 11.33 & 1.86 & 2.38 & 1.39 & 0.04 & 0.26 & 3982 \\
\hline$C V$ & 8.31 & 4.40 & 15.41 & 9.79 & 7.28 & 48.11 & 5.88 & 3.38 \\
\hline \multicolumn{9}{|l|}{ Brazil } \\
\hline$n$ & 15 & 14 & 15 & 15 & 15 & 10 & 14 & 10 \\
\hline Mean & 12.30 & 13.17 & 1.65 & 2.62 & 1.65 & 0.06 & 0.34 & 3957 \\
\hline$C V$ & 6.13 & 8.22 & 23.45 & 11.68 & 11.16 & 69.86 & 16.35 & 2.27 \\
\hline \multicolumn{9}{|l|}{ India } \\
\hline$n$ & 12 & 13 & 13 & 13 & 12 & 11 & 13 & 7 \\
\hline Mean & 10.91 & 11.70 & 1.74 & 2.42 & 1.61 & 0.07 & 0.30 & 4047 \\
\hline$C V$ & 4.80 & 3.78 & 17.82 & 8.94 & 7.64 & 31.16 & 12.25 & 3.59 \\
\hline \multicolumn{9}{|l|}{ Ukraine } \\
\hline$n$ & 13 & 13 & 13 & 12 & 13 & 11 & 13 & 12 \\
\hline Mean & 12.59 & 10.55 & 1.56 & 2.48 & 1.50 & 0.06 & 0.30 & 3980 \\
\hline$C V$ & 4.10 & 9.53 & 21.71 & 9.42 & 5.60 & 34.70 & 10.76 & 1.98 \\
\hline \multicolumn{9}{|c|}{ United States } \\
\hline$n$ & 11 & 12 & 12 & 12 & 12 & 10 & 12 & 7 \\
\hline Mean & 10.14 & 10.83 & 1.70 & 2.54 & 1.52 & 0.08 & 0.29 & 4058 \\
\hline$C V$ & 11.16 & 6.92 & 14.40 & 12.44 & 8.85 & 63.02 & 11.77 & 3.08 \\
\hline Maximum & 12.59 & 13.17 & 1.86 & 2.62 & 1.65 & 0.08 & 0.34 & 4058 \\
\hline Minimum & 10.14 & 10.55 & 1.56 & 2.38 & 1.39 & 0.04 & 0.26 & 3957 \\
\hline Average & 11.23 & 11.52 & 1.70 & 2.49 & 1.54 & 0.06 & 0.30 & 4005 \\
\hline \multicolumn{9}{|c|}{ Among countries } \\
\hline SEM & 0.31 & 0.31 & 0.12 & 0.09 & 0.05 & 0.01 & 0.01 & 48.9 \\
\hline$P$ value & $<0.001$ & $<0.001$ & 0.256 & 0.074 & $<0.001$ & 0.202 & $<0.001$ & 0.115 \\
\hline CV & 11.41 & 10.81 & 19.74 & 11.23 & 10.48 & 57.39 & 15.43 & 2.96 \\
\hline
\end{tabular}

$C P$ crude protein, $E E$ ether extract, $C F$ crude fiber, $C a$ calcium, $P$ phosphorus, GE gross energy, $C V$ coefficient of variation, $S E M$ standard error of the mean

a Values of "Hard red wheat" were used

depending on several factors such as cultivar (Murphy et al. 2008) and existence of toxins (Matthäus et al. 2004). Murphy et al. (2008) have indicated that mineral concentration in soft white wheat has decreased during the past 120 years, whereas the mineral concentration in hard red wheat has remained a constant concentration. It has been reported that wheat inoculated with Fusarium culmorum has significantly higher $\mathrm{CP}$ and ash contents than wheat without such inoculation (Matthäus et al. 2004).

The concentrations of moisture, $\mathrm{CF}, \mathrm{Ca}, \mathrm{P}$, and GE were different in barley samples from various countries $(P<0.05$; Table 3). The concentrations of $\mathrm{CP}$ in barley samples from Australia and India were lower than those of NRC (2012) or CVB (2009). However, barley samples from Ukraine had similar CP concentrations to those of CVB (2009). The Ca and $\mathrm{P}$ contents in barley samples from various countries had very small differences. The concentrations of $\mathrm{Ca}$ in barley ranged from $0.05 \%$ (Australia) to $0.07 \%$ (Ukraine). Phosphorus values ranged from $0.25 \%$ (India) to $0.28 \%$ (Australia). The averaged Ca values were similar to those of NRC (2012) and CVB (2009). However, the concentrations of P in the present study $(0.27 \%)$ were lower than the reference value $(0.35 \%)$ of NRC (2012) or CVB (2009). Barley samples from Australia had slightly higher GE value (4059 kcal/kg) than those from other countries. Nutrient compositions of barley may vary depending on various factors, including 
Table 3 Nutrient compositions of barley from different countries (as-is basis, \%)

\begin{tabular}{|c|c|c|c|c|c|c|c|c|}
\hline & Moisture & $\mathrm{CP}$ & $\mathrm{EE}$ & $\mathrm{CF}$ & Ash & $\mathrm{Ca}$ & $P$ & GE \\
\hline \multicolumn{9}{|l|}{ NRC (2012) } \\
\hline$n$ & 52 & 76 & 33 & 12 & 38 & 32 & 39 & 24 \\
\hline Mean & 10.10 & 11.33 & 2.11 & 3.90 & 2.38 & 0.06 & 0.35 & 3939 \\
\hline$C V$ & 26.24 & 13.59 & 30.81 & 17.95 & 17.65 & 33.33 & 11.43 & 2.21 \\
\hline \multicolumn{9}{|l|}{ CVB (2009) } \\
\hline Mean & 13.10 & 10.40 & 1.70 & 4.60 & 2.10 & 0.06 & 0.35 & N/A \\
\hline \multicolumn{9}{|l|}{ Australia } \\
\hline$n$ & 34 & 32 & 34 & 34 & 34 & 28 & 32 & 29 \\
\hline Mean & 10.54 & 9.75 & 2.11 & 4.46 & 2.02 & 0.05 & 0.28 & 4059 \\
\hline$C V$ & 7.61 & 15.97 & 13.93 & 16.84 & 8.13 & 21.58 & 13.43 & 2.38 \\
\hline \multicolumn{9}{|l|}{ India } \\
\hline$n$ & 17 & 19 & 19 & 16 & 18 & 19 & 18 & 17 \\
\hline Mean & 10.26 & 9.46 & 2.14 & 5.81 & 2.10 & 0.06 & 0.25 & 3894 \\
\hline$C V$ & 9.36 & 4.59 & 25.67 & 3.91 & 7.14 & 26.05 & 11.17 & 2.72 \\
\hline \multicolumn{9}{|l|}{ Ukraine } \\
\hline$n$ & 7 & 7 & 6 & 7 & 7 & 7 & 7 & 7 \\
\hline Mean & 12.32 & 10.49 & 2.18 & 4.61 & 2.07 & 0.07 & 0.27 & 3918 \\
\hline$C V$ & 5.99 & 3.70 & 8.12 & 6.59 & 4.83 & 23.71 & 4.59 & 2.38 \\
\hline Maximum & 12.32 & 10.49 & 2.18 & 5.81 & 2.10 & 0.07 & 0.28 & 4059 \\
\hline Minimum & 10.26 & 9.46 & 2.11 & 4.46 & 2.02 & 0.05 & 0.25 & 3894 \\
\hline Average & 11.04 & 9.90 & 2.15 & 4.96 & 2.06 & 0.06 & 0.27 & 3957 \\
\hline \multicolumn{9}{|c|}{ Among countries } \\
\hline SEM & 0.24 & 0.37 & 0.11 & 0.14 & 0.04 & 0.004 & 0.01 & 25.7 \\
\hline$P$ value & $<0.001$ & 0.232 & 0.907 & $<0.001$ & 0.159 & $<0.001$ & 0.013 & $<0.001$ \\
\hline CV & 9.83 & 13.87 & 17.59 & 15.94 & 7.79 & 28.84 & 13.08 & 2.98 \\
\hline
\end{tabular}

$C P$ crude protein, $E E$ ether extract, $C F$ crude fiber, $C a$ calcium, $P$ phosphorus, GE gross energy, $C V$ coefficient of variation, SEM standard error of the mean

cultivar (Gahoonia and Nielsen 1997), hulling process (Mitchall et al. 1976; Sumner et al. 1985), and weather (Leyshon and Sheard 1974). Gahoonia and Nielsen (1997) have suggested that barley cultivar with longer root hairs has better ability to absorb inorganic P from soil. It has been reported that hull-less barley has higher protein levels than covered barley (Mitchall et al. 1976; Sumner et al. 1985). However, the concentrations of indispensable amino acid in hull-less barley are not as high as the concentration of CP (Rhodes and Jenkins 1975; Sumner et al. 1985). In addition, Leyshon and Sheard (1974) have reported that the amount of nitrogen, $\mathrm{P}$, and potassium in barley are decreased under short-term flooding condition.

Coefficient of variation $(\mathrm{CV}, \%)$ was used to estimate the variabilities in nutrient compositions. The concentration of $\mathrm{Ca}$ had relatively high $\mathrm{CV}$ in all ingredients because cereal grain contains very small amount of $\mathrm{Ca}$. Therefore, a very small difference in Ca value could affect CV greatly. The CV values of corn in NRC (2012) for most nutrients except the $\mathrm{Ca}$ and GE were greater than those of the present study because NRC (2012) had much more nutrients data than this study. In addition, analyzed value of each nutrient might be different. Therefore, variation of nutrient in NRC (2012) could be greater than that of the current study. The CV values of GE in individual ingredients in this study were similar to those values of NRC (2012).

\section{Conclusion}

Results of this study provided more detailed information about nutrient components of major cereal grains imported to Korea from various countries. There were some variations in nutrition contents depending on countries. Therefore, it is necessary to consider where these ingredients come from when formulating animal feeds in order to meet nutrient requirements accurately.

\section{Authors' contributions}

JL: Drafted manuscript. DSN: Revised manuscript. CK: Gave advice for experimental work and manuscript preparation. All authors read and approved the final manuscript.

\section{Acknowledgements}

This research was supported by a Grant (NRF-2015R1C1A1A02036777) of the Basic Science Research Program through the National Research Foundation of Korea (NRF) funded by the Ministry of Science, ICT and Future Planning, Republic of Korea. This research was also supported by the KU Research Professor Program of Konkuk University. 


\section{Competing interests}

The authors declare that they have no competing interests.

Received: 30 December 2015 Accepted: 23 March 2016 Published online: 06 April 2016

\section{References}

Abbas HK, Cartwright RD, Xie W, Shier WT (2006) Aflatoxin and fumonisin contamination of corn (maize, Zea mays) hybrids in Arkansas. Crop Prot 25:1-9

Acharya CL, Sharma PD (1994) Tillage and mulch effects on soil physical environment, root growth, nutrient uptake and yield of maize and wheat on an Alfisol in north-west India. Soil Tillage Res 32:291-302

Cromwell GL, Calvert CC, Cline TR, Crenshaw JD, Crenshaw TD, Easter RA, Ewan RC, Hamilton CR, Hill GM, Lewis AJ, Mahan DC, Miller ER, Nelssen JL, Pettigrew JE, Tribble LF, Veum TL, Yen JT (1999) Variability among sources and laboratories in nutrient analyses of corn and soybean meal. J Anim Sci 77:3262-3273

CVB (2009) CVB Table booklet feeding of poultry. CVB series no. 45 Zoetermeer, the Netherlands

Ewan RC (1989) Predicting the energy utilization of diets and feed ingredients by pigs. In: van der Honing Y, Close WH (eds) Proceeding of the EAAP. Pudoc, Wageningen, p 1989

Feil B, Moser SB, Jampatong S, Stamp P (2005) Mineral composition of the grains of tropical maize varieties as affected by pre-anthesis drought and rate of nitrogen fertilization. Crop Sci 45:516-523

Gahoonia TS, Nielsen NE (1997) Variation in root hairs of barley cultivars doubled soil phosphorus uptake. Euphytica 98:177-182

Harder HJ, Carlson RE, Shaw RH (1982) Yield, yield components, and nutrient content of corn grain as influenced by post-silking moisture stress. Agron J 74:275-278

Jadhav SJ, Lutz SE, Ghorpade VM, Salunkhe DK (1998) Barley: chemistry and value-added processing. Food Sci Nutr 38:123-171

Kaiser DE, Mallarino AP, Bermudez M (2005) Corn grain yield, early growth, and early nutrient uptake as affected by broadcast and in-furrow starter fertilization. Agron J 97:620-626

Leyshon AJ, Sheard RW (1974) Influence of short-term flooding on the growth and plant nutrient composition of barley. Can J Soil Sci 54:463-473

MacGregor AW, Bhatty RS (eds) (1993) Barley: chemistry and technology. Am Assoc Cereal Chemists, St. Paul, MN
MAFRA (2015) Ministry of Agriculture, Food and Rural

Affairs, Republic of Korea. http://www.mafra.go.kr/list.

jsp?id=30673\&pageNo=1\&NOW_YEAR=2015\&group_id=1\&menu_ id=52\&link_menu_id=\&division=B\&board_kind=C\&board_skin $\mathrm{id}=$ C1\&parent_code $=34 \&$ link_url $=\&$ depth $=2 \&$ code $=$ left $\&$ link_target_yn=\&menu_introduction=\&menu_name=\%C3\%D6\%B1\%D9\%C5 \%EB\%B0\%E8\%CO\%DA\%B7\%E1\&popup_yn=N\&reference=2\&tab_yn=N. Accessed 20 Jan 2015

Matthäus K, Dänicke S, Vahjen W, Simon O, Wang J, Valenta H, Meyer K, Strumpf A, Ziesenib H, Flachowsky G (2004) Progression of mycotoxin and nutrient concentrations in wheat after inoculation with Fusarium culmorum. Arch Anim Nutr 58:19-35

Mitchall KG, Bell JM, Sosulski FW (1976) Digestibility and feeding value of hulless barley for pigs. Can J Anim Sci 56:505-511

Murphy KM, Reeves PG, Jones SS (2008) Relationship between yield and mineral nutrient concentrations in historical and modern spring wheat cultivars. Euphytica 163:381-390

NRC (2012) Nutrient requirements of swine, 11th rev edn. Natl Acad Press, Washington, DC

Rhodes AP, Jenkins G (1975) The effect of varying nitrogen supply on the protein composition of a high lysine mutant of barley. J Sci Food Agric 26:705-709

Rodrigues I, Naehrer K (2012) A three-year survey on the worldwide occurrence of mycotoxins in feedstuffs and feed. Toxins 4:663-675

Skogerson K, Harrigan GG, Reynolds TL, Halls SC, Ruebelt M, landolino A, Pandravada A, Glenn KC, Fiehn O (2010) Impact of genetics and environment on the metabolite composition of maize grain. J Agric Food Chem 58:3600-3610

Sumner AK, Gebre-Egziabher A, Tyler RT, Rossnagel BG (1985) Composition and properties of pearled and fines fractions from hulled and hull-less barley. Cereal Chem 62:112-116

Ufaz S, Galili G (2008) Improving the content of essential amino acids in crop plants: goals and opportunities. Plant Physiol 147:954-961

Watson SA, Ramstad PE (1987) Corn: chemistry and technology. Am Assoc Cereal Chemists, St. Paul, MN

Zijlstra RT, de Lange CFM, Patience JF (1999) Nutritional value of wheat for growing pigs: chemical composition and digestible energy content. Can J Anim Sci 79:187-194

\section{Submit your manuscript to a SpringerOpen ${ }^{\circ}$ journal and benefit from:}

- Convenient online submission

- Rigorous peer review

- Immediate publication on acceptance

- Open access: articles freely available online

- High visibility within the field

- Retaining the copyright to your article

Submit your next manuscript at $>$ springeropen.com 